\title{
くシンポジウムN $>$
}

\section{回復期リハビリテーション病院における心原性脳塞栓症の 再発予防の現状と提言}

\author{
酒向 正春1 ${ }^{1}$ 石川 誠 ${ }^{1}$ 堀 智勝2) \\ 1)初台リハビリテーション病院脳卒中診療科， ${ }^{2}$ 東京女子医科大学脳神経外科
}

(脳卒中 $28: 583,2006$ )

【目的】心原性脳塞栓症は急性期治療と同様に再発予 防が重要である。そこで，心原性脳塞栓症患者の回復 期リハビリテーション病院入院時のワーファリン治療 の現状と退院時を比較検討する、【方法】対象は 2004 年 1 年問に当院に入院した脳梗塞 248 例中心原性脳塞 栓症 85 例 $(73.6 \pm 12$ 歳)である. 入院時ワーファリン 治療 (WT) の有無を急性期施設別，診療科別，年齢別 PT-INR 值で検討し，当院退院時の治療の有無と年齢 別 PT-INR 值を比較検討した【成績】1) 入院時にWT がなされた心原性脳塞栓症例は 46 例（54\%：72.8土 12.9 歳) であった. 2) 施設別のWT 率は大学病院 28 例，国公立病院 22 例，公的病院 17 例，民間病院 18 例中それぞれ $64 ， 50 ， 59 ， 39 \%$ であり，診療科別では 脸外科 35 例, 神経内科 21 例, 一般内科 11 例, 循環器 科 10 例，老年科 4 例，総合診療科 3 例，外科 1 例中そ

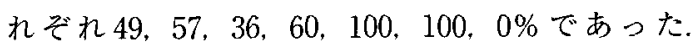

3）WT 例の入院時 PT-INR は 70 藏未満（15例）で $1.60 \pm 0.38 .70$ 歳以上 (31 例) で $1.92 \pm 0.48$ であった。

4）入院後にWTを開始した症例は39例中 13 例

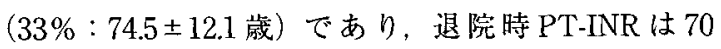
歳未満で $1.99 \pm 0.40,70$ 歳以上で $2.02 \pm 0.46$ であっ た．5）ワーファリン非治療例は 26 例 $(67 \%: 75.3 \pm 9.7$ 歳)であり，治療方針は前医に従い18例が抗血小板療 法，9例は無治療であった，6）再発例は 1例で，入院 1 週間後に発症し予後不良であった. [結論】急性期施 設での心原性脳塞栓症のWT 実施率は $54 \%$ であり， 大学病院, 循環器科系では高率であったが, PT-INR 管理は 70 歳未満では不十分であった. 一方, 回復期施 設でのWT 開始率は $33 \%$ に過ざなかった. 急性期, 回 復期施設とも一貫した心原性脳塞栓症に対する再発予 防の認識を高める必要性が示唆される. 